\title{
KEKUATAN HUKUM AKTA PERDAMAIAN YANG DIBUAT DIHADAPAN NOTARIS DAN PUTUSAN AKTA PERDAMAIAN PENGADILAN
}

\author{
Yanuar Rozi Firmansyah \\ Program Magister Kenotariatan Fakultas Hukum Universitas Brawijaya \\ Jl. MT. Haryono No 169; Malang; 65145; Indonesia; (0341) 553898 \\ yanuarah@gmail.com
}

\begin{abstract}
The making of authentic deed is one of notary authority in making deed. The realization of the verdict of the peace deed which obtains the force of law remains voluntary and execute. Deed of peace of civil case in court related to notary authority in making peace deed. The legal power of a peace deed made by a notary and a verdict of a peace deed of the court in a land rights sale disposal dispute. Notary's authority to make a peace deed to the land rights sale disputes related to the decision of a permanent law-enforcement law deed. The notarial deed of peace has three types of proof, in the form of external proof power, the power of formal proof, the power of material proof. A peace deed made before a notary has the power of an ordinary judge's verdict which has had a permanent legal force. Notary is required to register in court through the process of lawsuit. If during a peace deed made before a notary public is not registered in court then the peace deed is still in the form of agreement only.
\end{abstract}

Keyword: Settlement Agreement, Notary, Purchase of the Land, Land Dispute

\begin{abstract}
Abstrak
Pembuatan akta otentik merupakan salah satu kewenangan notaris dalam pembuatan akta. Realisasi putusan akta perdamaian yang telah memperoleh kekuatan hukum tetap dijalankan dengan sukarela dan eksekusi. Akta perdamaian pada perkara perdata di pengadilan terkait kewenangan notaris dalam pembuatan akta perdamaian. Kekuatan hukum akta perdamaian yang dibuat oleh notaris dan putusan akta perdamaian pengadilan dalam sengketa jual beli hak atas tanah. Kewenangan notaris membuat akta perdamaian terhadap sengketa jual beli hak atas tanah terkait putusan akta perdamaian pengadilan yang berkekuatan hukum tetap. Akta notaris perdamaian memiliki ketiga jenis pembuktian, yang berupa kekuatan pembuktian lahiriah, kekuatan pembuktian formal, kekuatan pembuktian materil. Akta perdamaian yang dibuat di hadapan notaris mempunyai kekuatan seperti suatu putusan hakim yang biasa yang telah mempunyai kekuatan hukum yang tetap. Notaris wajib mendaftarkan dalam pengadilan melalui proses gugatan. Apabila selama akta perdamaian yang dibuat dihadapan notaris tidak didaftarkan di pengadilan maka akta perdamaian tersebut masih dalam bentuk perjanjian saja.
\end{abstract}

Kata Kunci: Akta Perdamaian, Notaris, Jual Beli Tanah, Sengketa Tanah 


\section{Kekuatan Hukum Akta Perdamaian yang Dibuat Dihadapan Notaris dan Putusan Akta Perdamaian Pengadilan \\ Yanuar Rozi Firmansyah}

\section{Pendahuluan}

Semakin terbatasnya persediaan tanah dan semakin meningkatnya kebutuhan akan tanah, maka sesuai dengan hukum permintaan dan penawaran. Tanah memiliki fungsi dan kedudukan yang sangat strategis, baik secara sosial, ekonomi maupun politik (Joni, 2016). Hal ini akan meningkatkan potensi untuk timbulnya sengketa pertanahan ataupun konflik-konflik yang berhubungan dengan atau yang disebabkan oleh tanah. Dibutuhkan suatu perangkat hukum dan sistem admistrasi pertanahan yang teratur dan tertata rapi untuk menghilangkan atau paling tidak mengurangi kemungkinan terjadinya perkara tanah dan sengketa tanah, sehingga dapat memberikan jaminan dan mampu untuk memberikan perlindungan terhadap pemilik tanah serta dapat mengatur kepemilikan, peralihan dan peruntukan tanah secara adil dan menyeluruh. Tidak seimbangnya antara persediaan tanah dengan kebutuhan akan tanah itu, telah menimbulkan persoalan dalam berbagai segi.

Sengketa-sengketa demikian tidak dapat diabaikan tanpa ditangani dengan sungguh-sungguh. Penyelesaian permasalahan sengketa tanah masyarakat dominan memilih jalur pengadilan (litigasi) sebagai proses untuk mencari keadilan dan kepastian hukum. Oleh karena itu, secara teoritis dalam proses beracara di pengadilan dikenal adanya asas sederhana, cepat dan berbiaya ringan, namun apabila mencermati realita kasus-kasus dan sengketa perdata yang digelar di Pengadilan Negeri, Pengadilan Tinggi maupun Mahkamah Agung ternyata membuktikan proses pengadilan (litigasi) memakan waktu, biaya, tenaga dan pikiran.

Pasal 130 Het Herziene Indonesisch Reglement (selanjutnya disebut dengan HIR), Pasal 154 Rechtsreglement voor de Buitengewesten (selanjutnya disebut dengan RBg) memberikan pedoman bagi hakim untuk wajib mengusahakan dengan sungguh-sungguh penyelesaian dengan perdamaian bagi para pihak yang bersengketa. Berdasar pada Pasal 130 ayat (1) memberi arahan bahwa ketika pada hari yang telah ditentukan datang kedua belah pihak, maka Pengadilan Negeri melalui ketuanya wajib mencari jalan damai bagi keduanya. Hasil dari perdamaian itu harus dituangkan dalam sebuah surat (akta) yang berkekuatan seperti sebuah putusan hakim biasa, di mana tidak dapat dilakukan upaya hukum lagi setelahnya (Pasal 130 ayat (2) dan (3) HIR).

Pasal 1 angka 1 Peraturan Mahkamah Agung Republik Indonesia Nomor 1 Tahun 2016 tentang Prosedur Mediasi di Pengadilan menyebutkan bahwa akta perdamaian adalah akta yang memuat isi kesepakatan perdamaian dan putusan hakim yang menguatkan kesepakatan perdamaian tersebut yang tidak tunduk pada upaya hukum biasa maupun luar biasa. Wawan Muhwan Hariri (2011), Akta yang memuat kesepakatan perdamaian ini dapat berupa akta di bawah tangan maupun akta otentik yang dibuat oleh seorang notaris. Notaris merupakan pejabat umum yang berwenang untuk membuat akta otentik dan memiliki kewenangan lainnya sebagaimana dimaksud dalam UndangUndang ini atau berdasarkan undang-undang lainnya. Kewenangan lainnya diatur dalam Pasal 15 Undang-Undang Nomor 2 Tahun 2014 tentang Perubahan Atas Undang-Undang Nomor 30 Tahun 2004 Tentang Peraturan Jabatan Notaris.

Akta perdamaian merupakan salah satu produk hukum yang dibuat oleh notaris. Karena pembuatan akta otentik adalah salah satu kewenangan notaris dalam pembuatan akta. Namun penjelasan mengenai kewenangan notaris tidak memuat ketentuan mengenai pembuatan akta perdamaian terkait sengketa tanah. Kenyataannya dijumpai akta perdamaian yang dibuat notaris yaitu akta perdamaian.

Tentang duduk perkara dalam Pengadilan Negeri Nganjuk dengan nomor perkara: 39/ Pdt.G/2016/PN. Njk. merupakan jual beli antara Soewardi Sastro Admojo sebagai penjual dan Tohom Edison Tampubolom sebagai pembeli dengan objek tanah sertipikat hak milik nomor 424 
tahun 1991. Tanggal 09 Agustus 2002 Soewardi Sastro Admojo telah meninggal dunia. Tanggal 24 Januari 2014 tanpa seijin ahli waris dari almarhum Soewardi Sastro Admojo dan almarhumah Soemilah, tanah obyek sengketa dilakukan proses transaksi jual beli tercatat dalam Akta Jual Beli Nomor: 16/I/ 2014 antara Pihak Penjual Soewardi Sastro Admojo dengan Pihak Pembeli Tohom Edison Tampubolom dihadapan Notaris selaku Pejabat Pembuat Akta Tanah yaitu H. Ainur Rofiq, S.H., (Tergugat II), yang selanjutnya oleh Kantor Pertanahan Kabupaten Nganjuk (Tergugat III) telah disahkan dalam sertipikat hak milik nomor 424 tahun 1991 (tanah obyek sengketa) terjadi perubahan pemilik dari nama Soewardi Sastro Admojo menjadi nama Tohom Edison Tampubolom.

Penghadap yang menghadap Notaris selaku Pejabat Pembuat Akta Tanah yaitu H. Ainur Rofiq, S.H., (Tergugat II) yang mengaku bemama Soewardi Sastro Admojo adalah bukan Soewardi Sastro Admojo yang sebenamya, karena pada tanggal 09 Agustus 2002 Soewardi Sastro Admojo telah meninggal dunia. Namun, sertifikat tersebut di jual kembali oleh Tohom Edison Tampubolon kepada YusikArianto (Tergugat 1). Sehingga, para ahli waris mengajukan gugatan ke Pengadilan Negeri Nganjuk. Namun, dalam putusan 39/Pdt. G/2016/ PN. Njk dalam akta perdamaian penandatanganannya tidak menghadirkan beberapa pihak yang terkait dengan perkara tersebut. Putusan tersebut tidak dapat dijalankan, karena belum ada kepastian hukum bagi pihak-pihak yang tidak diikut sertakan dalam perdamaian.

Pihak-pihak berkehendak untuk melakukan upaya damai. Akta perdamaian dibuat karena dikehendaki oleh pihak yang berkepentingan untuk memastikan hak dan kewajiban para pihak demi kepastian, ketertiban, dan perlindungan hukum bagi pihak yang berkepentingan. Akta perdamaian yang dijalankan bukan putusan akta perdamaian pengadilan, tetapi akta perdamaian yang dibuat oleh para pihak dihadapan notaris X nomor 90 di Kabupaten Nganjuk berkedudukan di Jalan MT Haryono Nomor 3 yang merupakan bentuk perjanjian pada umumnya. Berdasar pada putusan 39/Pdt. G/2016/PN. Njk dalam akta perdamaian penandatanganannya tidak menghadirkan beberapa pihak yang terkait dengan perkara tersebut. Putusan tersebut tidak dapat dijalankan, karena belum ada kepastian dan perlindungan hukum bagi pihak-pihak yang tidak diikut sertakan dalam perdamaian.

Soedharyo Soimin, (2016) Pembuatan akta perdamaian diatur dalam Pasal 1851 KUHPerdata mengatur bahwa perdamaian dapat dilakukan atas perkara yang telah ada baik sedang berjalan di pengadilan atau akan diajukan kepengadilan. Namun pada kenyataannya akta perdamaian tersebut dibuat setelah adanya putusan perdamaian oleh pengadilan. Terkait kewenangan notaris dalam hal pembuatan akta perdamaian setelah adanya putusan pengadilan tidak di atur dalam undang-undang, sehingga dalam hal ini terjadi kekosongan hukum.

Selain itu terkait tentang kepastian hukum akta perdamaian yang dibuat notaris tidak memiliki kekuatan eksekutorial, layaknya seperti putusan akta perdamaian dalam sengketa perdata. Sehingga akta perdamaian notaris dapat dipermasalahkan dikemudian hari, apabila menimbulkan kerugian bagi pihak-pihak lain.

Berdasar pada uraian latar belakang diatas, permasalahan dalam penelitian ini disusun beberapa masalah. Adapun tujuan dalam penulisan ini adalah memberikan pengetahuan tentang hakikat dan pentingnya akta perdamaian pada perkara perdata di pengadilan terkait kewenangan notaris dalam pembuatan akta perdamaian. Kekuatan hukum suatu akta perdamaian yang dibuat oleh notaris dan putusan akta perdamaian pengadilan dalam sengketa jual beli hak atas tanah. 


\section{Kekuatan Hukum Akta Perdamaian yang Dibuat Dihadapan Notaris dan Putusan Akta Perdamaian Pengadilan \\ Yanuar Rozi Firmansyah}

\section{Metode Penelitian}

Penelitian ini adalah penelitian yuridis normatif yang difokuskan untuk mengkaji penerapan kaidah-kaidah atau norma-norma dalam hukum positif. Serta menelaah norma hukum dalam peraturan perundang-undangan. Mukti Fajar ND dan Yulianto Achmad, (2010) Pertimbangan titik tolak penelitian adalah analisa terhadap bahan hukum primer berupa peraturan perundangundangan yang terkait, bahan hukum sekunder, maupun bahan hukum tersier untuk memberi jawaban permasalahan mengenai Kekuatan Hukum Akta Perdamaian Yang Dibuat Dihadapan Notaris Terhadap Sengketa Jual Beli Hak Atas Tanah Terkait Putusan Akta Perdamaian Pengadilan.

\section{Hasil dan Pembahasan}

Penyelesaian atas perkara perdata termasuk sengketa terkait sengketa jual beli hak atas tanah mengacu pada ketentuan sebagaimana diatur dalam hukum acara perdata. Dimulai dengan adanya gugatan ke pengadilan diikuti dengan proses mediasi penyelesaian perkara yang berakhir dengan akta perdamaian di muka pengadilan Peraturan Mahkamah Agung No 1 Tahun 2016 tentang Prosedur Mediasi di Pengadilan, mewajibkan terlebih dahulu ditempuh upaya perdamaian dengan bantuan mediator. Paling lama sehari setelah sidang pertama para pihak harus memilih mediator yang dimiliki oleh Pengadilan dan yang tidak tercantum dalam daftar Pengadilan. M. Yahya Harahap, (2016) Apabila tidak tercapai kesepakatan mengenai mediator tersebut maka wajib menunjuk mediator dari daftar yang disediakan oleh Pengadilan saja. Apabila hal tersebut tidak juga berhasil, dalam jangka waktu satu hari kerja berdasarkan penetapan, Ketua majelis berwenang menunjuk seorang mediator.

Terdapat beberapa syarat formal yang harus dipenuhi oleh para pihak yang bersengketa untuk dapat dilakukannya upaya perdamaian, antara lain adanya Persetujuan Kedua Belah Pihak. Dalam usaha melaksanakan perdamaian yang dilakukan oleh Majelis Hakim didalam persidangan, kedua belah pihak harus bersepakat dan menyetujui dengan suka rela untuk mengakhiri perselesihan yang sedang berlangsung. Setelah perjanjian perdamaian tersebut disepakati dan ditandatangani oleh kedua belah pihak yang bersengketa, maka selanjutnya para pihak yang bersengketa mengajukan kesepakatan perdamaian yanhg telah dicapainya tersebut kepada Hakim untuk dikuatkan dalam bentuk akta perdamaian.

Pentingnya akta perdamaian serta hakikat akta perdamaian dari hasil mediasi adalah kesepakatan untuk mengakhiri sengketa antar kedua belah pihak. Dengan adanya kesepakatan para pihak dapat menciptakan solusi, serta perdamaian tidak menentukan siapa yang menang dan siapa yang kalah. Perdamaian merupakan bentuk alternatif penyelesaian sengketa yang dapat di capai dengan memenangkan kedua belah pihak (win-win solution). Kesepakatan tersebut di tuangkan dalam bentuk tulisan, dan bagi para pihak didalamnya wajib menaati isi dari akta perdamaian yang dibuat. Selain itu itikad baik dalam menyelesaikan sengketa merupakan hal utama yang menjadi dasar dalam melakukan kesepakatan perdamaian. Oleh karena itu, akta perdamaian harus berlandaskan kesepakan para pihak untuk mengakhiri sengketa, agar terlaksananya isi dalam akta perdamaian membutuhkan itikad baik dari kedua belah pihak yang bersengketa untuk melaksanakan isi dari akta perdamaian.

Pembuatan akta perdamaian yang dibuat dihadapan notaris, diatur dalam pasal 1851 KUHPerdata, bahwa Perdamaian dibuat buat sebelum sengketa terjadi dan/atau saat sengketa tersebut diperiksa di pengadilan dan akta tersebut dibuat secara tertulis. Secara tertulis dalam hal ini dapat dibuat dalam bentuk dibawah tangan atau dapat dibuat secara otentik. Perjanjian perdamaian di luar sidang pengadilan sebaiknya dilakukan da- 
lam bentuk akta otentik, supaya nanti apabila diajukan gugatan ke pengadilan, akta tersebut mempunyai kekuatan bukti sempurna atau tidak dapat disangkal lagi, isi akta tersebut dianggap benar dan hakim harus mempercayai apa yang ditulis di dalamnya. Akta tersebut hanya dapat dilemahkan apabila terdapat bukti perlawanan yang kuat (sebagai contoh, akta otentik itu bisa dinyatakan palsu apabila pada waktu menghadap notaris orang tersebut sudah meninggal dunia atau sedang berada di luar negeri, sehingga orang tersebut tidak mungkin bisa melakukan tanda tangan di depan notaris pada saat itu).

Habib Adjie, (2009) Pasal 15 ayat (1) menegaskan bahwa akta otentik merupakan kewenangan bagi notaris. Akta otentik sediri menjadi pilihan utama masyarakat dikarenakan akta otentik memiliki kekuatan pembuktian yang kuat. Sehingga pembuatan akta perdamaian dapat dibuat dihadapan notaris dengan cara notaris mendengarkan serta menuangkan ketentuan yang dikehendaki oleh para pihak dalam hal ini menyelesaikan penyelesaiaan sengketa antar para pihak.

Analisis terhadap keabsahan Akta yang dibuat di hadapan Notaris jika terjadi pelanggaran terhadap Pasal 16 Ayat (1) Huruf (l) UndangUndang Nomor 2 Tahun 2014 tentang Jabatan Notaris (UUJN), ditegaskan bahwa; "Dalam menjalankan jabatannya Notaris berkewajiban membacakan akta di hadapan penghadap dengan dihadiri oleh paling sedikit dua orang saksi dan ditandatangani pada saat itu juga oleh penghadap, saksi, dan Notaris". Apabila syarat formal dalam pembuatan akta tidak dipenuhi, maka akta yang dibuat oleh Notaris hanya mempunyai kekuatan pembuktian sebagai akta di bawah tangan (Intan, 2016).

Berkaitan dengan kasus perdata putusan Pengadilan Negeri Nomor 90/PDT.G/2016/PN NJK kasus tersebut diakhiri perdamaian antaran kedua belah pihak. Namun putusan perdamaian tersebut dikesampingkan dan tidak dipergunakan oleh para pihak dengan semestinya. Sehingga para pihak bersepakat dalam hal ini membuat akta perdamaian baru dihadapan Notaris dengan nomor akta 30 dibuat dihadapan Notaris Sri Mulyani Notaris yang berkedudukan di Nganjuk.

Penggugat adalah para ahli waris dari pasangan suami isteri yang bernama almarhum Soewardi Sastro Admojo dan almarhumah Soemilah. Yang semasa hidupnya pernikahan antara Soewardli Sastro Admojo dan Soemilah memiliki 5 (lima) orang anak kandung yang bernama Suwarniyanto (Penggugat 1), Tatiek Suharto, Sumiyah Tri Wulandari, Sunarto (Penggugat 2) dan Widyastuti (Penggugat 3). Yang dalam hal ini dari lima orang anak tersebut diatas telah meninggal dua orang yaitu almarhumah Tatiek Suharto dan almarhumah Sumiyah Tri Wulandari. Bahwa almarhummah Tatiek Suharto meninggalkan tiga orang anak yang bernama Yudhi Prabowo (Penggugat 4), Beni Cahyo Kuncoro (Penggugat 5) dan Oktaviana Tri Kanthi Handayani (penggugat 6). Sedangkan almarhumah Sumiyah Triwulandari meninggalkan dua orang anak yang bernama Elistya Widyawati (Penggugat 7) dan Lyana Novitasari (Penggugat 8).

Pasangan suami isteri Soewardi Sastro Admojo dan Soemilah selain meninggalkan keturunan sebagaimana disebutkan dalam huruf A tersebut diatas juga meninggalkan harta warisan yang berwujud 1 (satu) bidang tanah dan bangunan yang terletak di Kelurahan Ganung, Kecamatan Nganjuk, Kabupaten Nganjuk yang tercatat dalam sertipikat hak milik nomor 424 tahun 1991 dengan batasbatas:

1. Tanah Milik Sri Bidaryati

2. Tanah Milik Santoso

3. Jalan Megantoro

4. Saluran air

Duduk perkara dalam Pengadilan Negeri Nganjuk dengan nomor perkara: 39/ Pdt.G/2016/ PN. Njk. merupakan jual beli antara Soewardi 
Sastro Admojo sebagai penjual dan Tohom Edison Tampubolom sebagai pembeli dengan objek tanah sertipikat hak milik nomor 424 tahun 1991. Tanggal 09 Agustus 2002 Soewardi Sastro Admojo telah meninggal dunia. Pada tanggal 24 Januari 2014 tanpa seijin ahli waris dari almarhum Soewardi Sastro Admojo dan almarhumah Soemilah, tanah obyek sengketa dilakukan proses transaksi jual beli tercatat dalam Akta Jual Beli Nomor: 16/I/2014 antara Pihak Penjual Soewardi Sastro Admojo dengan Pihak Pembeli Tohom Edison Tampubolom dihadapan Notaris selaku Pejabat Pembuat Akta Tanah yaitu H. Ainur Rofiq, S.H., (Tergugat II), yang selanjutnya oleh Kantor Pertanahan Kabupaten Nganjuk (Tergugat III) telah disahkan dalam sertipikat hak milik Nomor 424 Tahun 1991 (tanah obyek sengketa) terjadi perubahan pemilik dari nama Soewardi Sastro Admojo menjadi nama Tohom Edison Tampubolom.

Penghadap yang menghadap Notaris selaku Pejabat Pembuat Akta Tanah yaitu H. Ainur Rofiq, S.H., (Tergugat II) yang mengaku bemama Soewardi Sastro Admojo adalah bukan Soewardi Sastro Admojo yang sebenamya, karena pada tanggal 09 Agustus 2002 Soewardi Sastro Admojo telah meninggal dunia. Namun, sertifikat tersebut di jual kembali oleh Tohom Edison Tampubolon kepada YusikArianto (Tergugat 1). Sehingga, para ahli waris mengajukan gugatan ke Pengadilan Negeri Nganjuk.

Pembacaan gugatan dilaksanakan pada tanggal 20 September 2016 dan dihadiri oleh seluruh pihak. Setelah pembacaan gugatan hakim memberi kesempatan para pihak untuk melakukan mediasi. Melalui proses mediasi para pihak sepakat mengadakan perdamaian, mereka memilih hakim mediator dari pengadilan, namun salah satu pihak dari Badan Pertanahan Wilayah Nganjuk tidak dihadirkan dalam melaksanakan mediasi tersebut.

Pihak masih bersengketa dikarenakan salah satu pihak tidak dihadirkan dalam mediasi, sekalipun telah mendapat putusan perdamaian dari pengadilan. Sehingga para pihak melakukan perdamaian sekali lagi dihadapan notaris Sri Mulyani Notaris Wilayah Nganjuk. Namun diketehui bahwa sampai sekarang sengketa tersebut masih berlangsung, dikarenakan dalam akta perdamian tidak memuat bagaimana objek sengketa tersebut akan dialihkan atau diserahkan pada tergugat.

Sudikno Mertokusumo (2002), dalam praktek di masyarakat, eksistensi notaris dalam pembentukan hukum tercermin dari partisipasi Notaris sebagai mediator dalam berbagai perselisihan antar pihak selama para pihaknya itu merupakan kliennya dalam urusan keperdataan. Meski tugas utama notaris adalah membuat atau mencatatkan kejadian secara otentik, keikutsertaan peran Notaris lebih dari yang diatur didalam undang-undang khususnya sebagai mediator dalam perbedaan pandangan terhadap sesuatu dalam hubungan hukum antar dua kliennya menjadi sangat memungkinkan. Bagi pihak yang membuat suatu perjanjian dihadapan Notaris, apabila terjadi suatu konflik atau sengketa yang berhubungan dengan akta tersebut, maka biasanya orang pertama yang diminta nasihat adalah Notaris yang bersangkutan.

Prakteknya suatu perjanjian perdamaian adalah merupakan suatu akta, karena perjanjian tersebut sengaja dibuat oleh pihak-pihak yang bersangkutan untuk dijadikan alat bukti dengan tujuan untuk menyelesaikan sengketa, untuk itu perjanjian perdamaian haruslah memenuhi kriteria sebagai berikut:

1. Akta perdamaian dalam bentuk akta otentik Suatu perjanjian perdamaian yang dibuat dalam bentuk akta otentik memenuhi ketentuanketentuan sebagai berikut, Akta itu harus dibuat "dihadapan" seorang pejabat umum. Kata "dihadapan" menunjukkan bahwa akta tersebut digolongkan ke dalam akta partij (partij akten), dan pejabat umum yang dimaksud adalah Notaris. Dalam akta partij, pihak-pihak yang terlibat dalam suatu sengketa telah setuju untuk menyelesaikan sengketa di luar peng- 
adilan dan telah berhasil mencapai suatu kesepakatan tertentu, kemudian mereka datang ke Notaris untuk membuat suatu perjanjian perdamaian yang dituangkan dalam bentuk akta otentik.

2. Akta itu harus dibuat dalam bentuk yang ditentukan oleh undang-undang. Berdasarkan Pasal 1868 Kitab Undang-Undang Hukum Perdata, akta otentik dalam bentuk menurut undang-undang harus memenuhi formalitas tertentu. Dalam praktek notariat, bentuk tertentu dari Notaris yang lazim dipergunakan terdiri dari tiga bagian yaitu:

\section{a. Kepala Akta ;}

Terdiri dari judul akta, hari dan tanggal akta, nama notaris, tempat kedudukannya, serta komparisi (nama para penghadap, jabatan dan tempat tinggalnya, beserta keterangan apakah ia bertindak untuk diri sendiri atau sebagai wakil/kuasa dari orang lain beserta atas kekeuatan apa ia bertindak, sebagai wali atau kuasa).

b. Badan Akta ;

Menyebutkan ketentuan atau perjanjian apa saja yang dikehendaki oleh para penghadap sepanjang tidak bertentangan dengan undang-undang, ketertiban umum dan kesusilaan.

Badan akta terdiri dari premisse (keterangan pendahuluan yang disampaikan oleh para penghadap, dalam hal mengenai akta perjanjian damai ini, dijelaskan mengenai adanya sengketa dan keterangan-keterangan lain yang dianggap perlu) dan klausul-klausul (biasanya dituangkan dalam bentuk pasal-pasal yang berisikan mengenai kesepakatan yang harus dipatuhi oleh para pihak). Klausul-klausul tersebut berupa:

1. Sepakat untuk mengakhiri sengketa

2. Penyerahan objek yang disengketakan

3. Sanksi apabila salah satu pihak melakukan wanprestasi
4. Pembebanan biaya pembuatan akta perdamaian

c. Akhir Akta / Penutup.

Merupakan suatu bentuk yang memuat tempat dimana akta itu dibuat dan diresmikan serta menyebut nama, jabatan dan tempat tinggal para saksi pelengkap yang menyaksikan pembuatan akta tersebut (saksi instrumentair). Selanjutnya di bagian penutup ini disebutkan bahwa akta itu dibacakan kepada para penghadap dan saksi-saksi, dan setelah itu ditandatangani oleh para penghadap, saksi-saksi dan Notaris.

3. Notaris tersebut harus mempunyai wewenang untuk membuat akta itu.

Seorang notaris hanya berwenang membuat akta yang memang ditugaskan kepadanya, karena tidak semua akta dapat dibuat oleh notaris. Wewenang untuk membuat suatu akta perjanjian perdamaian memang ada di tangan seorang notaris, karena pejabat umum lainnya tidak diperbolehkan untuk membuat akta tersebut. Notaris tidak berwenang untuk membuat akta untuk dirinya sendiri, isteri atau suaminya, keluarga sedarah atau keluarga semenda dari notaris itu sendiri dalam garis lurus tanpa pembatasan derajat dan garis kesamping sampai dengan derajat ketiga. Selain itu seorang notaris hanya berwenang untuk membuat akta di dalam daerah yang ditentukan baginya sepanjang ia masih memegang jabatannya sebagai notaris.

Agar perjanjian perdamaian memenuhi ketentuan hukum harus Memenuhi ketentuan pasal 1320 KUHPerdata, yaitu tentang sahnya suatu perjanjian, berikut penulis jelaskan tentang pengertian perjanjian dan memenuhi Pasal 1851 ayat (2) KUHPerdata, menentukan perjanjian perdamaian dibuat secara tertulis. Sebagai suatu akta yang otentik maka akta perdamaian yang dibuat diha- 
dapan notaris itu memiliki kekuatan pembuktian yang lengkap. Bukti lengkap ialah bukti yang sedemikian sehingga hakim memperoleh kepastian yang cukup (genoegzaam) untuk mengabulkan akibat hukum yang dituntut oleh penggugat, tanpa mengurangi kemungkinan ada bukti tentang kebalikannya. Untuk itu, akta notaris perdamaian notaris adalah akta otentik yang memiliki ketiga jenis pembuktian, yaitu:

1. Kekuatan Pembuktian Lahiriah (uitwendige bewijskracht)

Kemampuan lahiriah akta otentik merupakan kemampuan akta itu sendiri untuk membuktikan keabsahannya sebagai akta otentik atau dalam bahasa latinnya adalah acta publica probant sesse ipsa artinya jika dilihat dari luar atau lahirnya sebagai akta otentik serta sesuai dengan aturan hukum yang sudah ditentukan mengenai syarat akta otentik maka akta tersebut berlaku sebagai akta otentik sampai terbukti sebaliknya artinya sampai ada yang membuktikan bahwa akta tersebut bukan akta otentik secara lahiriah. GHS Lumban Tobing (1983), Dengan kekuatan pembuktian lahiriah ini dimaksudkan kemampuan dari akta itu sendiri untuk membuktikan dirinya sebagai akta otentik.

Kemampuan ini menurut Pasal 1875 KUHPerdata tidak dapat diberikan kepada akta yang dibuat di bawah tangan, akta yang dibuat di bawah tangan baru berlaku sah, yakni sebagai yang benar-benar berasal dari orang, terhadap siapa akta itu dipergunakan, apabila yang menandatanganinya mengakui kebenaran dari tanda tangannya itu. Apabila sesuatu akta kelihatannya sebagai akta otentik, artinya menandakan dirinya dari luar, dari kata-katanya sebagai yang berasal dari pejabat umum, maka akta itu terhadap setiap orang dianggap sebagai akta otentik, sampai dapat dibuktikan bahwa akta itu bukan akta otentik. Sepanjang mengenai kekuatan pembuktian lahiriah ini, yang merupakan pembuktian lengkap dengan tidak mengurangi pembuktian sebaliknya maka akta partij dan akta pejabat dalam hal ini adalah sama. Suatu akta yang dari luar kelihatannya sebagai akta otentik, berlaku sebagai akta otentik terhadap setiap orang, tanda tangan dari pejabat yang bersangkutan (notaris) diterima sebagai sah. Kekuatan pembuktian lahiriah ini tidak ada pada akta di bawah tangan. Nilai pembuktian akta notaris dari aspek lahiriah, akta tersebut harus dilihat apa adanya, secara lahiriah tidak perlu dipertentangkan dengan alat bukti yang lain, jika ada yang menilai suatu akta notaris tidak memenuhi syarat sebagai akta otentik, maka yang bersangkutan wajib membuktikan bahwa akta tersebut secara lahiriah bukan akta otentik.

2. Kekuatan Pembuktian Formal (Formele bewijskracht)

Akta notaris harus memberikan kepastian bahwa suatu kejadian dan fakta tersebut dalam akta betul-betul dilakukan oleh notaris atau diterangkan oleh pihak-pihak yang menghadap pada saat yang tercantum dalam kata sesuai dengan prosedur yang sudah ditentukan dalam pembuktian akta. Secara formal untuk membuktikan kebenaran dan kepastian tentang hari, tanggal, bulan, tahun, pukul atau waktu menghadap, dan identitas dari para pihak yang menghadap comparanten, paraf dan tanda tangan para pihak/penghadap, saksi serta notaris, demikian juga tempat di mana akta itu dibuat, serta membuktikan apa yang dilihat, disaksikan, didengar oleh notaris. Sjaifurrachman dan Habib Adjie (2011), untuk itu, jika terdapat pihak yang mempermasalahkan aspek formal dari akta tersebut maka pihak tersebut harus dapat membuktikan ketidakbenaran tersebut. Jika tidak mampu membuktikan ketidakbenaran tersebut, maka akta tersebut harus diterima oleh siapapun. 
3. Kekuatan Pembuktian Materil (Materiele bewijskracht)

Sepanjang yang menyangkut dengan kekuatan pembuktian material dari suatu akta otentik, terdapat perbedaan antara keterangan dari notaris yang dicantumkan dalam akta itu dan keterangan dari para pihak yang tercantum didalamnya. Tidak hanya kenyataan, bahwa adanya dinyatakan sesuatu yang dibuktikan oleh akta itu, akan tetapi juga isi dari akta itu dianggap dibuktikan sebagai yang benar terhadap setiap orang, yang menyuruh adakan/ buatkan akta itu sebagai tanda bukti terhadap dirinya atau yang dinamakan "prevue preconstituee", akta itu memunyai kekuatan pembuktian material. Kekuatan pembuktian inilah yang dimaksud dalam Akta notaris sebagai akta otentik memiliki kekuatan bukti yang lengkap atau sempurna dan memiliki kekuatan mengikat, serta telah mencukupi batas minimal alat bukti yang sah tanpa lagi diperlukan alat bukti lain dalam suatu sengketa perdata. Menurut Pasal 1870 KUHPerdata bahwa suatu akta otentik memberikan di antara para pihak beserta ahli warisnya atau orang yang mendapatkan haknya dari mereka suatu bukti yang sempurna tentang apa yang dimuat di dalamnya. Akta otentik merupakan suatu bukti yang mengikat dalam arti bahwa apa yang ditulis dalam akta tersebut harus dipercaya oleh hakim, yaitu harus dianggap sebagai benar selama ketidak benarannya tidak dibuktikan.

Joni Emerson (2001), Akta perdamaian notaris sebagai akta otentik memberikan suatu bukti yang sempurna dalam arti bahwa ia sudah tidak memerlukan suatu penambahan pembuktian. Akta otentik itu tidak hanya membuktikan bahwa para pihak sudah menerangkan apa yang ditulis disitu, tetapi juga bahwa apa yang diterangkan itu adalah benar. Notaris diberi wewenang untuk menuangkan semua perbuatan, perjanjian, dan penetapan yang dikehendaki oleh pihak atau pihak-pihak yang sengaja datang kehadapn notaris untuk mengkonstatir keterangan itu dalam suatu akta otentik, dan agar akta yang dibuatnya itu memiliki kekuatan bukti yang lengkap dan memiliki keabsahannya. Notaris wajib memenuhi semua ketentuan-ketentuan jabatan notaris dan peraturan-peraturan lainnya karena notaris bukan juru tulis semata-mata. Dengan demikian, notaris wajib mengaji apakah yang diinginkan penghadap untuk dinyatakan dalam akta otentik, tidak bertentangan dengan Undang-Undang Jabatan Notaris dan aturan hukum yang berlaku bagi akta otentik.

Akta perdamaian yang dibuat di hadapan notaris mempunyai kekuatan seperti suatu putusan hakim yang biasa yang telah mempunyai kekuatan hukum yang tetap (in kracht vangewijsde), namun hal tersebut notaris wajib mendaftarkan nya dalam pengadilan melalui proses gugatan selama akta perdamaian yang dibuat dihadapan notaris tidak di daftarkan di pengadilan maka akta perdamaian tersebut masih dalam bentuk perjanjian saja yang mengikat para pihak yang membuatnya. Berkaitan dengan eksekusi dan/atau penyerahan objek sengketa bersifat sukarela bagi salah satu pihak yang di wajibkan menyerahkan objek sengketa tersebut.

\section{Kesimpulan}

Pentingnya akta perdamaian serta hakikat akta perdamaian dari hasil mediasi adalah kesepakatan untuk mengakhiri sengketa antar kedua belah pihak. Dengan adanya kesepakatan para pihak dapat menciptakan solusi, serta perdamaian tidak menentukan siapa yang menang dan siapa yang kalah. Perdamaian merupakan bentuk alternatif penyelesaian sengketa yang dapat di capai dengan memenangkan kedua belah pihak (win-win solution). Akta perdamaian dapat memberikan jaminan kepastian hukum bagi para pihak yang 
bersengketa. Akta perdamaian yang ditandatangani akan mengikat para pihak seperti layaknya undangundang bagi para pihak dan akta perdamaian tersebut memiliki kekuatan eksekutorial apabila dimintakan putusan kepada pengadilan.

\section{Saran}

Bagi Pengadilan, hakim harus berperan aktif untuk mendorong masyarakat menempuh perdamaian harus lebih intensif, utamanya dengan member pengertian bahwa akta perdamaian dapat memberikan kepastian hukum dan perlindungan hukum bagi para pihak yang bersengketa. Notaris harus pro aktif dalam memberikan saran-saran hukum agar para pihak dalam menuangkan kesepakatan tetap pada rule hukum yang benar dan mencapai kesepakatan yang fair.

\section{DAFTAR PUSTAKA}

Adjie, Habib dan Sjaifurrachman. 2011. Aspek Pertanggungjawaban Notaris Dalam Pembuatan Akta. Mandar Maju. Bandung.

Adjie, Habib. 2009. Sekilas Dunia Notaris dan PPAT di Indonesia. Mandar Maju. Jakarta.

Emerzon, Joni. 2001. Alternatif Penyelesaian Sengketa di Luar Pengadilan. Gramedia Pustaka Utama. Jakarta.

Fajar N.D., Mukti dan Yulianto, Achmad. 2010. Dualisme Penelitian Hukum Normatif dan Hukum Empiris. Pustaka Pelajar. Yogyakarta.

Harahap, M yahya. 2016. Hukum Acara Perdata tentang Gugatan, Persidangan, Penyitaan, Pembuktian dan putusan pengadilan, Cetakan Ke enam belas. Sinar Grafika. Jakarta.

Intan, L. 2016. Akibat Pelanggaran Oleh Notaris Terhadap Pembuatan Akta Notariil. Jurnal Cakrawala Hukum, 7(2), 206-215. doi:10.26905/ idjch.v7i2.1909.
Joni, H. 2016. Tanah Sebagai Aset Sosial Dalam Perspektif Hukum Agraria Nasional. Jurnal Cakrawala Hukum, 7(1), 123-134. doi:10.26905/idjch. v7i1.1787.

Kitab Undang-Undang Perdata.

Mertokusumo, Sudikno. 2002. Hukum Acara Perdata. Liberty. Yogyakarta.

Peraturan Mahkamah Agung Republik Indonesia Nomor 1 Tahun 2016 Tentang Prosedur Mediasi di Pengadilan (Berita Negara Republik Indonesia Tahun 2016 Nomor 175).

Peraturan Menteri Agraria dan Tata Ruang/ Kepala Badan Pertanahan Nasional Republik Indonesia Nomor 11 Tahun 2016 tentang Penyelesaian Kasus Pertanahan (Berita Negara Republik Indonesia Nomor 569 Tahun 2016).

Soimin, Soedharyo. 2016. Kitab Undang-Indang Hukum Perdata, Cetakan Keenam belas. Sinar Grafika, Jakarta.

Subekti, R. 2005. Kamus Hukum, cet.16. Pradnya Paramiata. Jakarta.

Tobing, G.H.S. Lumban. 1983. Peraturan Jabatan Notaris. Erlangga, Jakarta.

Undang-Undang Nomor 2 tahun 2014 tentang Perubahan Atas Undang-Undang Nomor 30 Tahun 2004 Tentang Peraturan Jabatan Notaris (Lembaran Negara Republik Indonesia Tahun 2014 Nomor 3 Tambahan Lembaran Negara Republik Indonesia Nomor 5491).

How to cite:

Firmansyah, Y. R. 2017. Kekuatan Hukum Akta Perdamaian yang Dibuat Dihadapan Notaris dan Putusan Akta Perdamaian Pengadilan. Jurnal Cakrawalah Hukum, 8(2). 